\title{
Vapen, våld och vi-platser \\ Skändande av helgedomar som maktstrategi i det vikingatida Skandinavien
}

Olof Sundqvist

Stockholms universitet, Sverige

I de norröna källorna omtalas platser som på grund av rituella sanktioner inte fick kränkas med till exempel vapen och våldshandlingar. Enligt Egils saga kap. 56 tycks tingsplatsen vid Gula på Vestlandet i Norge ha haft den statusen. ${ }^{\mathrm{I}}$ Det sägs där att på tingsplatsen var marken slät och hasselstänger var nedstuckna i ring på ängen. Vid dem var ett snöre fästat som kallades fridsband (vébond). Inne i ringen satt de som dömde, tolv domare från respektive fylke (totalt trettiosex domare från tre fylken). Vid denna plats mötte sagans hjälte Egill vid ett tillfälle sin ärkefiende kung Eiríkr och hans gemål drottning Gunnhildr. Egill var på tinget för att kräva ut ett arv som kungens vän, Berg-Qnundr, orättmätigt lagt beslag på. Egill lade fram sin sak väl och krävde att domarna skulle ge honom hans egendom enligt lagen. Då domarna efterhand blev övertygade om att Egils argument var välgrundade och underbyggda av vittnen grep kungaparet in, där Gunnhildr tycks ha varit den mest aktiva parten. Hon lät kungens hirdmän springa fram till tingsplatsen. De skar ned fridsbanden, bröt ned stängerna och jagade bort domarna. I denna berättelse är det kungaparet som bryter tingsfriden och skändar tingsplatsen genom att låta sina män attackera den och skära ned fridsbanden. Benämningen på dessa fridsband, vébond, indikerar att platsen där domarna satt var helig. Ordet vé betyder nämligen 'helig plats'. Det kommer

Hur du refererar till det här kapitlet:

Sundqvist, O. 20I6. Vapen, våld och vi-platser. Skändande av helgedomar som maktstrategi i det vikingatida Skandinavien. I: Rydving, H. and Olsson, S. (red.) Krig och fred i vendel- och vikingatida traditioner, s. I67-I95. Stockholm: Stockholm University Press. DOI: http://dx.doi.org/IO.I6993/bah.h. License: CC-BY 4.0 
också fram i texten att männen på tingsplatsen var obeväpnade. Det var endast skändarna som bar vapen.

Som religionshistoriker måste man självfallet diskutera historiciteten för denna berättelse. De isländska familjesagorna anses generellt ha ett lågt källvärde, eftersom de avhandlar ting som utspelades flera hundra år före nedtecknandet av texterna. Att Egill spelade en central roll i de makropolitiska händelserna som kom att leda till kung Eiríks fall är ytterst osäkert. Den idén hänger säkerligen samman med den isländska traditionen eller den isländske skrivaren som på olika sätt ville hylla islänningen Egill och samtidigt kritisera den norska monarkin. Likaså hänger troligen den aktiva roll som Gunnhildr har i sagan och den konversation som hon har med kungen ihop med sagans dramatiska och narrativa dimensioner. Det finns nämligen en samtida skaldevers (lausavisa) bevarad i sagan som indikerar att det snarare var kungen som betraktades som en helgedomsskändare av Egill och att det var han som stod bakom agerandet vid Gula. ${ }^{2}$

I den tidigare forskningen har man ofta noterat det samband som finns mellan religion och rätt i denna episod. Bo Frense, till exempel, tar i sin avhandling fasta på begreppet vébond och påpekar att dessa band gav tingsförhandlingarna en religiös förankring. Han menar också att man såg hela tingsplatsen som en helgedom. ${ }^{3}$ Andra forskare har förutom kopplingen mellan religion och rätt också tagit fasta på kungens agerande i berättelsen. I en intressant analys i boken Authority: Construction and Corrosion argumenterar Bruce Lincoln för att denna händelse kan ses som vändpunkten i sagan, vilken leder till kung Eiríks fall. ${ }^{4}$ Kungens auktoritet kollapsar nämligen då han bryter mot lagen och attackerar den heliga tingsplatsen (han kallas i en strof citerad i sagan logbrigðir, 'lagbrytaren'). Enligt Lincoln attackerar kungen egentligen den ideologi som fanns i det gamla fylkessamhället, där lagmännen (det vill säga fylkeshövdingarna) kollektivt vakade över rättsordningen. Eiríkr och drottning Gunnhildr visar med sina handlingar att den mer centraliserade kungamakten, som just inrättats i Norge av Eiríks far kung Haraldr, stod över fylkeshövdingarnas auktoritet och det gamla decentraliserade tingssamhället.

Det kan också finnas en ytterligare orsak bakom kungens fall. Kanske förlorar han sin auktoritet då han inte uppträder på ett 
för hövdingar förväntat sätt, nämligen som helgedomarnas beskyddare. I den vikingatida poesin och i vikingatida runinskrifter kunde kungar, jarlar och hövdingar nämligen benämnas vés valdr, 'kultplatsens beskyddare / härskare', vorðr véstalls, 'helgedomsaltarets beskyddare', eller "vévorðr, 'helgedomens beskyddare' (se vidare nedan). ${ }^{5}$ Enligt min mening hänger dessa benämningar samman med den religiösa härskarideologi som fanns i Norge, Island och Svetjud under vikingatiden, där hövdingen bland annat skulle beskydda de gudomliga makterna då de besökte de jordiska helgedomarna och förse dem med offergåvor. Dessutom uppfattades helgedomen troligen som ett mikrokosmos av den mytiska världen och det "rike" som förknippades med makthavaren. ${ }^{6}$ Det var en stor förödmjukelse för en kung eller hövding om en utmanare offentligt skändade hans helgedom, det vill säga den viktigaste symbolen för hans välde. Att rituellt skända en helgedom kunde således vara en god strategi för den som ville utmana om makten. Troligen var denna rituella handling en konvention som alla kände till i det instabila vikingatida samhället. En sådan offentlig och performativ handling kunde innehålla våldsamma inslag, som syftade till att symboliskt och konkret skada den som vakade över kultplatsen och att förändra maktbalansen. Med performativitet menar jag här att handlingen eller ritualen har förändringskapacitet, där fokus läggs på handlingens effekt eller verkan. Uppmärksamheten vänds således mot handlingens intention, vad den utträttar, och hur den påverkar de individer som tagit del av den. ${ }^{7}$

I föreliggande undersökning kommer jag att ta min utgångspunkt i de rituella restriktioner som enligt denna saga och andra källor fanns i anslutning till vikingatida tings- och kultplatser i Norge och på Island (även i Sverige) och då i synnerhet sådana som omfattar restriktioner rörande våld och vapen. I källorna betecknas sådana platser ofta med substantivet vé, men de kan också beskrivas med termerna heilagr eller helgi. Jag kommer att föreslå en hypotes, nämligen att skändandet av tings- och kultplatser i det vikingatida Skandinavien skulle kunna ses som en medveten strategi att förödmjuka och krossa den härskare eller auktoritet som vakade över den heliga platsen. ${ }^{8}$ I Egils saga skulle kungaparets attack vid Gula kunna betraktas som en medveten, performativ 
handling, som syftade till att tillintetgöra den auktoritet som ansvarade över och skyddade helgedomsfriden vid tingsplatsen, det vill säga de trettiosex domarna och de lokala hövdingarna från de tre fylkena, Fjordane, Sogn och Horda. Med denna handling ville de förändra rådande maktförhållanden. I min studie kommer jag att ge flera exempel på sådana performativa rituella handlingar, där kultplatser skändas med kränkningar, våld och vapen, och där syftet ytterst tycks vara att tillintetgöra den auktoritet som stod bakom helgedomarna. Jag kommer dock att inleda med en diskussion om kultplatsernas karaktär och utformning, samt ta upp de rituella restriktioner som fanns där, i syfte att skapa en kontext till min undersökning.

\section{Kultplatsernas benämningar och karaktär}

I de skriftliga källorna förekommer ofta det fornvästnordiska ordet vé som beteckning för kultplats. En ekvivalent term i det östnordiska sammanhanget är termen $v i$. Detta ord är en substantivering av ett urgermanskt adjektiv *wīhaz, 'helig', som också är relaterat till tyskans Weihnachten, 'jul'. 9 Innebörden av ordet $v i$ är således 'något heligt' eller 'helig plats'. Det finns som sagt också andra viktiga termer i de fornskandinaviska språken som förekommer i anslutning till kultplatser, nämligen adjektivet fvn. heilagr, 'helig', och substantivet fvn. helgi, 'helighet'. ${ }^{\circ}$ Den medeltida kyrkan tog tidigt upp dessa termer i sin nomenklatur och lät dem ersätta begreppen sacer och sanctus. Man ansåg uppenbarligen att de var användbara också i ett kristet sammanhang.

Då vi tolkar dessa vikingatida begrepp måste vi vara medvetna om att deras betydelse inte utan vidare kan föras samman med det helighetsbegrepp som kom att utvecklas bland protestantiska och liberalteologiska forskare i början av I900-talet. ${ }^{\text {II }}$ Det heliga uppfattades där som en okränkbar ontologisk essens eller mystisk och opersonlig kraft, som människan kunde erfara på ett intuitivt sätt. Det heliga manifesterade sig i den profana världen genom gudar, heliga föremål och heliga platser och så vidare. Huruvida denna uppfattning av "det heliga" kan appliceras på en fornskandinavisk kontext är mycket osäkert. Då vi tolkar termerna vé, heilagr och helgi måste vi vara medvetna om det. 
Troligtvis har det funnits en betydelseskillnad mellan vé och heilagr. Kanske kan man komma åt den genom att studera ordens etymologi. Adjektivet *wīhaz är bildat till roten *weik-, 'separera' och senare 'separera åt högre makter'. ${ }^{12}$ Kanske har ordet tillämpats då man skulle urskilja heliga föremål, heliga platser och så vidare. Den substantiverade formen $v i$ har tidigt berört en rumslig dimension. Så långt bak vi kan följa ordet betyder det 'helig plats'. Det är faktiskt den enda betydelse vi kan belägga i de nordiska språken. Ordet heilagr hänger troligen samman med adjektivet heill, 'odelad, oskadad, frisk', eller möjligen substantivet fvn. heill, 'lycka, (gott eller ont) varsel, tecken'. Om man tar fasta på adjektivet rör heilagr kanske den läkande aspekten av heligheten. Walter Baetke hävdade dock i sin klassiska studie Das Heilige im Germanischen att heilagr utgår från substantivet och redan under förkristen tid hade en religiös betydelse. ${ }^{\mathrm{I} 3}$ Den lycka som begreppet betecknar kom ursprungligen från gudomen och förmedlades till människan via offerkulten.

Källorna avslöjar inte om begreppet vi syftar på en bestämd typ av kultplats eller om det är en samlingsbeteckning för kultplatser i allmänhet. I både edda- och skaldedikter betecknar ordet vé mer allmänt 'gudarnas boning', och syftar då både på platser i den mytiska och den reella världen. ${ }^{14}$ Att $v i$-platser i den reella världen tillägnades enskilda gudar vittnar ortnamnen om. I Sverige, till exempel, uppträder $v i$ ofta som huvudled i teofora ortnamn, till exempel Frösvi, Torsvi, Odensvi och Ullevi. ${ }^{15}$ Omdiskuterad är sammansättningen Götavi, som kan innehålla folkslagsbeteckningen "götar". Per Vikstrand argumenterar för att den innehåller en teofor förled, nämligen gudanamnet *Gauti, som troligen syftar på Óðinn. ${ }^{\mathrm{I}}$

De berättande källorna kan stundtals ge vissa upplysningar om de aktiviteter som utfördes vid ett $v i$. I den tidigmedeltida Gutasagan, till exempel, omtalas ett "blot i vi". Utsagan antyder att ett vi på Gotland kunde vara en plats där man bedrev kult. I Gutasagan framgår det också att man kunde få asyl vid ett $v i$, eftersom våldshandlingar var förbjudna där. ${ }^{17}$ I den fornvästnordiska litteraturen uppträder termen vé också i förleden till en rad sammansatta ord, som kan ge oss indikationer på hur en $v i$ plats var utformad. Jag har redan nämnt termen vébǫnd, 'banden 
vid helgedomen', som indikerar att $v i$-platser kunde vara rituellt avgränsade. ${ }^{8}$ I den gamla skaldedikten Ynglingatal finns sammansättningen véstallr, ${ }^{19}$ som kan betyda 'altare' eller 'podium för gudabilder'. Alltså, på en vi-plats kan det ha funnits ett slags rituella plattformar eller altare med gudabilder (se vidare nedan). Sammansättningen véstong, som finns belagd i ett poetiskt sammanhang i Háttatál, betyder ungefär 'stången vid helgedomen' och kan möjligen beteckna ett av objekten på en $v i$-plats. ${ }^{20} \mathrm{Vi}$ har också några andra sammansättningar som sällan påtalas, till exempel vébrandr, som skulle kunna översättas 'elden vid helgedomen'. ${ }^{21}$ Sammansättningen vébraut refererar eventuellt till ett slags processionsväg vid vi-helgedomen. ${ }^{22}$ Enligt de skriftliga källorna verkar det alltså som om det fanns vissa anläggningar och objekt vid $v i$-platserna, något som arkeologin i dag kan bekräfta, till exempel vid Lilla Ullevi och Götavi i Sverige. ${ }^{23}$ En vi-plats skulle således kunna betraktas som en större helgedom, som omfattade en rad olika rituella platser.

Som jag nämnde tidigare har vi också platser som kan karaktäriseras med adjektivet heilagr eller substantivet helgi. I namnet Helgö, som finns belagt i Ekerö sn, Uppland, har vi antagligen adjektivet som förled, 'helig'. ${ }^{24}$ I detta fall betraktas troligen hela ön som en helgad och sanktionerad plats. På Helgö har arkeologer hittat spår av rituella konstruktioner och kult, som kan dateras till yngre järnåldern. Dessa fynd är koncentrerade till öns östra och nordöstra delar. ${ }^{25}$ I Landnámabók så talas det om Moerinahelgi ${ }^{26}$ där är det också ett helt område som betraktas som heligt (se vidare nedan). Helt klart är dock också att en enskild plats eller byggnad kan karaktäriseras som helgistaðr, 'heilig stad' ${ }^{27}$

\section{Rituella restriktioner vid helgedomar}

I anslutning till de platser som betecknas med termerna vé, heilagr och helgi tycks det som sagt ha funnits rituella restriktioner mot att bära vapen eller att utföra våldshandlingar. I flera sammanhang återkommer Landnámabók just till den typen av bestämmelser. Det talas bland annat om en man kallad Váli i Kung Haralds hird, som dödade en annan man på en vi-plats och därför blev dömd fredlös. ${ }^{28}$ Liknande restriktioner omnämns även i Egils saga. Där 
omtalas ett dråp i en $v i$-helgedom, vilket bestraffades med fredlöshet. Det sägs också där att de andra männen som fanns i helgedomen var vapenlösa, eftersom hovet var helgat (hofshelgi). ${ }^{29}$ Enligt denna text betraktades den som bröt mot dessa restriktioner som en "varg”, det vill säga ett villebråd som man gärna fick döda. Det är också intressant att notera att vé i denna text används som en synonym till termen hof. I några fall tycks förekomsten av vapen på en helgad plats uppfattas som en kränkning mot gudomen, till exempel i Vatnsdoela saga..$^{\circ}$ Det finns en runinskrift i Östergötland från 8oo-talet, som indikerar att våldshandlingar var förbjudna vid vi-platser också i Östnorden. Oklundainskriften nämner i inledningen att Gunnarr hade gjort sig skyldig till ett brott och därför sökte skydd vid den $v i$-helgedom, som låg i Oklunda. Där kunde han vara fredad utan att bli dräpt till dess tingsdomen fallit:

kunar : fapirunaRpisaR : insa flausakaR sutiui pita

Gunnarr faði runaR pessaR. En sa flo sakR. Sotti vi petta ...

Gunnarr ristade dessa runor. Och han flydde 'saker' till ett brott. Sökte (skydd) i detta vi ... ${ }^{\text {I }}$

För att få mer utförlig information om de rituella bestämmelser som fanns vid vé- och helgi-platserna måste vi vända oss till det isländska materialet och några antaganden som gjorts i religionshistorisk forskning.

\section{Hövdingen inviger det sakrala landskapet och helgedomarna}

Det är känt från många kulturer i världen att då man inviger en kultplats måste vissa rituella handlingar utföras. ${ }^{32}$ Syftet med dessa handlingar är att separera det heliga området från den profana sfären. Området ska befrias från onda krafter och reserveras för gudomen. Det ska också bli en mötesplats mellan människan och den mytiska världen under kulten. I det invigda heliga området förekommer därför ofta specifika rituella restriktioner eller tabun, som varje person som anträder platsen måste förhålla sig till. Att liknande förhållanden existerat i det förkristna Skandinavien har vi redan delvis kunnat iaktta ovan. I de norröna texterna talas det om de ceremonier hövdingarna utförde vid invigningar av sakrala 
landskap och helgedomar under bebyggelsen av Island i slutet av 80o-talet. I en klassisk studie kallade Dag Strömbäck dessa ceremonier för "att helga land". ${ }^{3}$ Under dessa invigningsritual utlyste hövdingarna också rituella restriktioner inom det helgade området. I Landnámabók (och Eyrbyggja saga) berättas det bland annat om hövdingen Pórólfr från Mostr utanför Sunnhordaland, som byggde en gård vid Porsnes på västra Island och där reste en stor hovbyggnad, som han helgade åt Pórr. Texten berättar också att vid Porsnes fanns ett fjäll, som Pórólfr betraktade som så heligt, att ditåt fick ingen otvättad skåda och där fick inget levande skadas, varken människa eller djur. På den platsen rådde stor frid (mikil friðhelgi). På den heliga udden av näset inrättade han en tingsplats och på den heliga vallen fick ingen göra sitt tarv. ${ }^{34}$ Enligt Landnámabók utlyste även hövdingen Pórhaddr från Mære liknande rituella restriktioner mot våld då han anlände till Stödvarfjorden på östra Island:

Pórhaddr den gamle hovgode i Trondheim [dvs. Trøndelag] vid Mære. Han ville fara till Island, och innan han for tog han ned hovhelgedomen och förde med sig hovjorden och stolparna. Han kom till Stödvarfjorden och satte Moerina-helgi över hela fjorden, och ingen eller inget fick dräpas där förutom husdjuren på gården. ${ }^{35}$

(Min övers.)

Uttrycket Mcerina-helgi indikerar att han förde med sig den helighet och de rituella restriktioner som förknippades med den, från Mære i Trøndelag till Island.

Det verkar således som om det var hövdingen själv som utlyste de rituella restriktionerna vid helgedomarna. Med dessa performativa handlingar ville han troligen även signalera att det var han som hade makten lokalt och att man måste förhålla sig till hans påbud rent generellt.

\section{Helgedomens väktare}

I några av de refererade texterna ovan kommer det också fram att det var hövdingarna som övervakade att restriktionerna efterföljdes. I Landnámabók och Eyrbyggia saga, till exempel, berättas det att Porgrímr Kjallaksson och hans svåger inte ville respektera de 
rituella bestämmelser som Pórólfr fastställt vid den heliga tingsplatsen vid Pórsnes, genom att göra sitt tarv där. Pórsnesingarna kunde inte tåla detta och en strid bröt ut, där flera blev dödade. ${ }^{36}$ Man tvingades flytta tingsplatsen in på näset på grund av allt blod som runnit där. I beskrivningen av konflikten påpekas följande: "då blev vallen skändad av fiendeblod" (óheilagr af heiptarblóði). ${ }^{37}$ Förleden i ordet heiptarblóð är ordet heipt, 'fiendeskap, hat'. Helt klart uppfattade Pórsnesingarna det som en plikt att skydda det invigda området och de heliga restriktioner som deras frände Pórólfr tidigare statuerat där (se vidare nedan).

Även andra källor vittnar om att det var hövdingen, jarlen och till och med kungen som skulle vaka över helgedomarna och de rituella bestämmelserna. Det kommer fram redan i de tidiga vikingatida skaldedikterna. Ynglingatal, till exempel, berättar att enskilda härskare ur den berömda svensk-norska kungaätten Ynglingarna hade sådana funktioner. ${ }^{38}$ Enligt traditionen skulle den norske skalden Pjódólfr inn fróði ór Hvini ha diktat Ynglingatal cirka 890. Den dateringen har ifrågasatts av den norske historikern Claus Krag som menar att dikten kom till på ı ıoo-talet. Flera forskare (inklusive jag själv) har gått emot Krags förslag och hävdat att den traditionella dateringen ändå kan vara rimlig. ${ }^{39}$ Ynglingatal är en genealogisk dikt, som presenterar kungarnas död, begravningar och stundtals deras begravningsplatser. Språket i kvädet är ålderdomligt och präglat av kenningar och andra poetiska figurer. Kungarna uppträder ofta under en rad olika härskarbenämningar. I kvädet kallas, till exempel, sveakungen Yngvi för vorðr véstalls. Ordet $v$ grðr betyder här 'vårdare, beskyddare, bevakare, vakt, eller vaktman'. Den första leden i véstallr är det fornvästnordiska ordet vé som betyder 'helig plats, helgedom'. Handskrifterna har olika läsarter när det gäller den andra leden. Kringla har véstalls, vilket måste betraktas som den mest sannolika läsarten. Ordet stallr (m.) betyder egentligen 'fot, fotstycke, bas som något kan stå på'. I sammansättningen véstallr får ordet en religiös innebörd och kan betyda 'altare' eller 'podium för gudabilder'. Kenningen vorðr véstalls kan således tolkas som "helgedomsaltarets vårdare eller beskyddare".4 Denna benämning i Ynglingatal indikerar således att kungar rent allmänt prisades för att de hade en intim relation till helgedomen och de kultobjekt som fanns där. 
Även norska jarlar och kungar bär liknande benämningar som kung Yngvi. I dikten Sigurðardrápa (ca 960) hyllas Sigurðr jarl för hans frikostiga gästabud. Samtidigt sägs det att männen ska passa sig för att vredga jarlen. ${ }^{4 \mathrm{I}}$ I detta sammanhang kallas han för vés valdr "helgedomens härskare (beskyddare)". Kung Hákon den gode, som var samtida med Sigurðr jarl, beskrivs på ett liknande sätt i skaldedikten Hákonarmál. När kungen dog hyllade skalden honom på följande sätt: "då sades det hur väl kungen hade skyddat kultplatser (vel of pyrmt véum) ...". ${ }^{42}$ Verbet pyrma betyder egentligen 'skona, ha vördnad för, respektera', men kanske i överförd betydelse också 'skydda'.

Det verkar som om kungar och hövdingar rent allmänt i det förkristna Skandinavien hade en relation till helgedomar. På Rökstenen från Östergötland, till exempel, finns sekvensen sibi uiauari, som har tolkats "Sibbe, helgedomarnas väktare". ${ }^{43}$ Här är det alltså en östgötsk hövding eller en lokal härskare som är vårdare av $v i$-platserna. I en runinskrift $(\operatorname{Vg} 73)$ från Västergötland uppträder namnet Viurdr som kanske kan tolkas som ett ursprungligt binamn eller härskarepitet, fvn. *vévorðr (m.), 'helgedomsväktare'. ${ }^{44}$ I flera svenska runinskrifter förekommer namnet (eller binamnet) Vīseti (fvn. Véseti). ${ }^{45}$ Dessa namn eller epitet var troligen ursprungligen beteckningar för den hövding eller härskare, som uppträdde i den dubbla rollen som politisk och religiös ledare. Även i Landnámabók och de isländska sagorna kommer det fram att hövdingarna skulle vårda kultplatser och kultbyggnader (varðveitta hof). I Landnámabók sägs det bland annat att hövdingen Porbjorn hersir i Fjalafylki hade tagit hand om hovet $\mathrm{i}$ Gaular, ${ }^{46}$ medan den mäktige hövdingen Pórólfr, enligt Eyrbyggja saga, vårdade ett Pórshof på ön Mostr, utanför Sunnhordaland. ${ }^{47}$

Hur ska man då förklara denna koppling mellan härskaren och helgedomarna? Arkeologen Charlotte Fabech har hävdat att det sker en centralisering av offerkulten i Sydskandinavien under folkvandringstid. ${ }^{4}$ Offerceremonierna utfördes från stenåldern fram till romersk järnålder vid våtmarker, som låg långt från bebyggelsen. Men under folkvandringstid sker förändringar i offerpraxis. De offentliga offerceremonierna flyttas nu till den centrala bebyggelsen, främst härskarsäten och hövdingagårdar. Mönstret kan iakttas i arkeologiska källor. Man har till 
exempel funnit så kallade guldgubbar vid aristokratiska boplatser från yngre järnåldern, till exempel i Borg vid Lofoten, Slöinge i Halland, och Helgö vid Mälaren.49 Guldgubbarna med parmotiv avbildar troligen mytiska scener, eventuellt kärleksparet Freyr och Gerðr..$^{\circ \circ}$ Kanske fungerade de även som offer till gudarna eller som ett slags härskarsymboler. Det verkar således som en ny härskarideologi växer fram, där bland annat ritualer, symboler och andra religiösa uttryck blir betydelsefulla, till exempel hallar och kultbyggnader på stormannagårdar. Det faller sig då naturligt att härskaren framställs som "helgedomsväktaren”, eftersom helgedomen var hans egen egendom och lokaliserad på hans gård. Enligt min mening kan man förklara relationen mellan härskaren och helgedomen också på andra sätt, som hänger samma med ritualer, kult och härskarideologi.

Många forskare (inklusive jag själv) menar att helgedomen i vikingatidens Skandinavien stundtals tycks ha betraktats som en spegling av den mytiska världens topografi eller utgjorde ett slags mikrokosmos..$^{\text {I }}$ Kanske avspeglade helgedomen även kungens eller hövdingens rike, välde eller "värld", det vill säga att den uppfattades som den viktigaste symbolen för hans makt. Det är möjligen därför härskaren kallas "helgedomens väktare". I den maktkamp som pågick inom vikingatidens elit kan kränkandet av rituella restriktioner vid dessa symboliska platser ha varit ett slags konventionell maktstrategi. I det som följer ska jag presentera ett antal källor som visar att fienden till hövdingen, eller andra utmanare av makten, ofta strävade efter att komma åt just helgedomen och kränka den frid som rådde där med vapen eller andra medel. På så sätt förödmjukades den som förestod den heliga platsen och hans auktoritet kunde falla samman. ${ }^{52}$

\section{Skändande av helgedomar som maktstrategi}

Arkeologen Frands Herschend har hävdat att ett återkommande mönster kan iakttas i det arkeologiska materialet och även i skriftliga källor, nämligen att striderna till stor del går ut på att förstöra fiendehövdingens gästabudshall. ${ }^{53}$ Att äga en hall var, enligt Herschend, en maktmanifestation av hallens ägare. När man konkurrerar om makten var det därför viktigt för hallägarens 
fiender att förstöra byggnaden, eftersom den var den viktigaste symbolen för ledaren. Herschend påpekar således:

In Beowulf, king Hrōðgar flatters himself on having built a most splendid hall in the settlement where he lives and the act of building the hall plays an important role, being the inauguration of his kingship. Likewise the initial armistice at Finnsburg (Beowulf, vv. Io86-7) contained an agreement saying that a hall should be put in order for the thane of the slain Danish king Hnæf and his retainers. Clearly one cannot be a leader without a hall, however temporary. [...] sagas like the fight at Finnsburg have their obvious counterparts in the archaeological remains of the Late Iron Age. It seems fair to propose the hypothesis that the struggle for power among the leading families was to a certain degree a matter of fighting each other with the purpose of destroying each other's hall. Smashing rather than plundering was the keynote of this kind of political rather than economic warfare. ${ }^{54}$

Attackerna mot gästabudshallarna har ibland beskrivits som rituell krigföring. ${ }^{55}$ Det verkar som om de attackerande inte alltid strävade efter att stjäla eller plundra, trots att det har funnits många dyrbara objekt i dessa hus. Ett exempel på detta kan vi se i anslutningen till "krigarnas hall” vid Garnisonen på Birka. Den hallen tycks ha ödelagts i samband med stadens undergång på 900-talet. I resterna av den nedbrända hallen har man hittat exklusiva vapen, delar av sköldar och spjut, men också andra dyrbarheter, till exempel ett drakhuvud av brons, skärvor av glasbägare och beslag till kistor. Även utanför hallen hittades vapen. Trots att en del av dem troligen var brukbara har de inte samlats upp efter striden utan lämnats kvar på platsen. ${ }^{6}$ Det är mycket möjligt att dessa våldshandlingar ska tolkas som ett slags performativa ritual som syftade till att symboliskt bryta ner hallägarens "värld", hans "rike" och auktoritet. Kanske var det en stor förödmjukelse för en hövding som bar epitetet "helgedomens beskyddare" att inte lyckats skydda sin hall (som med största sannolikhet betraktades som ett rituellt och kanske också heligt rum för hövdingen och hans följe).

Det är möjligt att även drottning Gunnhildr och kung Eiríkr i Egils saga ville ifrågasätta de lokala myndigheterna och domstolen på Gulating, genom att låta deras följeslagare skära av fridsbanden (vébond), bryta hasselstängerna och vanhelga den heliga 
tingsplatsen (se ovan). Det skulle kunna ses som en avsiktlig rituell handling som syftade till att förnedra och underkänna tingsdomarna och den lokala auktoriteten, som var på väg att ge Egill rätt i tvisten. Enligt sagan jagade kungens hirdmän bort domarna från tingsplatsen på ett förnedrande och nedlåtande sätt. Genom denna handling fick kungaparet åtminstone tillfälligt ett maktövertag.

Ett liknande mönster kan vi iaktta i Eyrbyggja saga och Landnámabók, där en skändning av heligt område också används i en politisk maktkamp (se ovan). Porgrímr Kjallaksson och hans svåger förklarade offentligt under vårtinget vid Pórsnes att de inte längre skulle tolerera Pórsnesingarnas arrogans och bestämmelser, utan att de skulle göra sitt tarv på gräset vid tingsplatsen precis som de brukade göra vid andra tingsmöten. Sammanhanget visar helt tydligt att Kjalleklingarna ville utmana Pórsnesingarnas makt, det vill säga den familj som styrde i det lokala samhället, på tingsplatsen och vid helgedomen. Kjalleklingarnas syfte var helt klart att provocera och förödmjuka Pórsnesingarna, genom att bryta de rituella restriktioner och tabun som Pórólfr en gång instiftat vid Pórsnes. Kjalleklingarnas handlingar skulle kunna ses som en medveten rituell strategi för att tillägna sig den lokala makten. Dessa handlingar resulterar också i att Porgrímr Kjallaksson och Pórsteinn Pórólfsson fick dela omsorgen av hovet och uppbära hälften var av hovets intäkter. Det bestämdes också vid förlikningen att de skulle stå varandra bi och skänka stöd vid konflikter. Porgrímr fick dessutom titeln goði. ${ }^{57}$ Kjalleklingarnas hot om skändningar av och våldshandlingar vid den heliga tingsplatsen kom således att förändra maktförhållandena vid Pórsnes. Även det rituella landskapet förändrades. Enligt både Landnámabók och Eyrbyggia saga flyttades tingsplatsen till de östra delarna av näset efter striden och blodspillan på det heliga området. Den nya platsen var också betraktad som mycket helig (helgistaðr mikill).

I texter som skildrar övergångstiden är det helt klart att attacker och vanhelgande av kultbyggnader i Norge och Sverige var performativa handlingar som avsåg att utrota fiendens världsbild och religiösa värderingar. Visserligen har dessa handlingar en annan kontext än ovan nämnda exempel, men kanske syftade även de till att bryta ner lokala hövdingars auktoritet, precis som skändningarna gjorde i till exempel Egils saga. Snorri Sturluson 
rapporterar i Heimskringla hur helgedomar i Trøndelag under slutet av 900-talet förstördes av kung Óláfr Tryggvason när man inledde missionen i området. Den kristne kungens fiender var helt klart fylkeshövdingarna som ville bevara de gamla sederna och helgedomarna. I Óláfs saga Tryggvasonar, till exempel, beskriver Snorri hur kung Óláfr demonterade hof-byggnaden på Lade och tog bort all egendom och alla dekorationer från den och från kultbilderna..$^{58} \mathrm{Han}$ tog också ner en stor ring från dörren till byggnaden, varpå han lät bränna hela huset. ${ }^{59}$ Berättelsen handlar inte bara om att kultbyggnaden ska skändas utan även de rituella föremålen som fanns där, till exempel dekorationerna, kultbilderna och dörringen. Det kommer fram i texten att bönderna var mycket upprörda över kungens agerande och man skickade härpilar till varje fylke. Kung Óláfr tillämpade samma strategi då han deltog i offerfesten vid hovet i Mære, i de inre delarna av Trøndelag. Där slog han Pórs bild av helgedomspallen och dödade böndernas ledare, Járn-Skeggi.$^{60}$ De maktlösa fylkeshövdingarna klarade inte av att skydda helgedomarna i Trøndelag och förlorade därmed all sin auktoritet inför alla närvarande. Kungens förödmjukande handlingar och skändningar gjorde hövdingarna och bönderna svaga, och till slut accepterade de kristendomen och kung Óláfs styre.

Kyrkliga källor från England, skrivna på latin, rapporterar också att de kristna skändade de gamla helgedomarna med våld och vapen. Enligt Beda (700-t.) vanhelgade den före detta hedniske kultledaren Coifi en helgedom öster om York genom att kasta ett spjut in i det sakrala området. Han hade nämligen blivit omvänd och ville demonstrera sina nya tro genom att bryta mot de föreskrifter som fanns där. ${ }^{61}$ Kanske var denna spjutattack också riktad mot den lokala makten som inte förmådde att skydda helgedomen från våldshandlingar.

Adam av Bremen nämner att Adalvard den yngre kom till Svetjud, ivrig att predika evangeliet och raskt leda folket i Sigtuna och Uppland till den kristna tron. Adalvard och biskop Egino kom överens om att de skulle resa till det hedniska templet som kallas Uppsala för att pröva om de där kunde bringa Kristus någon frukt av sin möda. De var där villiga att utstå all slags pina, om det hus nedrevs, som var centrum för vantron. För när det rivits, eller helst nedbränts, skulle följden bli att hela befolkningen 
omvändes. Kung Stenkil fick dessa kyrkomän att avstå från sina planer, dels för att de skulle dödas och dels för att han själv skulle bli avsatt som kung eftersom han låtit dem komma in i sitt rike. ${ }^{62}$ Möjligtvis hänger denna rädsla hos kungen samman med idén att folket förväntade sig att deras makthavare skulle skydda helgedomarna i riket. Den kristne kungen visste att folket (som delvis fortfarande var anhängare av den gamla tron) troligen skulle ha uppfattat denna skändning som en stor förödmjukelse för honom och ett tydligt tecken på att han inte var kapabel att hålla eller vara värdig kungamakten.

\section{Återuppbyggandet av skändade helgedomarna som maktstrategi}

Det finns också texter som visar att skändade helgedomar kunde renoveras och återinvigas. Dessa renoveringar och invigningar skulle också kunna tolkas som ett slags maktstrategi, som syftade till att förändra en rådande maktbalans. Tankegången kommer fram i några skaldestrofer som har bevarats till eftervärlden genom manuskripten till Fagrskinna och Heimskringla. Heimskringla rapporterar att de kristna Eiríks-sönerna med våld rev ned hov och förstörde blotplatser när de kom till makten i Norge. Under deras år ödelades årsväxten. Men då Hákon jarl var i färd med att ta över makten bestämde han att männen skulle hålla hoven i stånd och fortsätta att blota. Som stöd för dessa utsagor hänvisar Snorri till några med händelserna samtida strofer ur Einarr skálaglamms Vellekla (ca 990):

[1 5] Oll lét senn enn svinni sonn Einriða monnum herjum kunn of herjuð hofs lond ok vé banda, ádr veg jotna vitni valfalls, of sjá allan, peim stýra goð, geira garðs Hlórriði farði.

[16] Ok herparfir hverfa Hlakkar móts, til blóta,
Den kloke lät snart alla Einrides hov och goda blotplatser, som hade härjats, komma till heder, innan härskaren for med höjda svärd över land och hav, gudarna styr honom.

Och de mansamlande asarna kommer till blot, som ger 
rauðbríkar fremsk rokir ríkr, ásmegir, sliku.

Nú groer jorð sem áðan.

Aptr geirbrúar hapta

auðrýrir loetr ōru

óhryggua vé byggva. den mäktige hövdingen

mycket stor heder.

$\mathrm{Nu}$ gror jorden som förr.

Guldslösaren låter

åter krigarna

sitta glada i hoven. ${ }^{63}$

(Text och översättning K. G. Johansson)

I strof I 5 berättas det således att jarlen lät snart alla Einriða (det vill säga Pórs) hovland och gudarnas helgedomar som tidigare härjats komma till heder. I nästa strof ( I6) sägs det att gudarna återkommer till bloten. Nu gror jorden som förr och jarlen låter åter krigarna sitta glada i helgedomarna. Enligt min mening omfattar dessa strofer ett härskarideologiskt budskap. En legitim härskare måste skydda helgedomarna från våld och vanhelgande för att kunna upprätthålla en bra relation till gudarna. Genom de kultiska aktiviteterna får han en gudomlig vägledning och hans land kan blomstra. Det paradisliknande tillstånd som skapas under jarlen i Norge liknar den mytiska värld som enligt Voluspá uppstod efter Ragnarök. I Vellekla får således jarlens gärningar en kosmisk betydelse. ${ }^{64}$ Dikten visar att även Hákons renovering och återinvigning av de skändade helgedomarna var en viktig strategi för honom att få legitimitet som hövding. Med dessa handlingar signalerade han offentligt att maktbalansen förändrats. Det var Hákon jarl som från och med nu ledde landet med stöd av gudarna.

\section{Konklusion}

I föreliggande studie har jag presenterat en hypotes om våldshandlingar vid helgedomar som maktstrategi i det förkristna Norge, Sverige och på Island. Helgedomarna betecknas i de inhemska källorna där ofta med substantivet vé, men de kan också beskrivas med termerna heilagr eller helgi. Helgedomen betraktades som ett mikrokosmos av den mytiska världen, där gudar och människor kunde mötas. Kanske var den också en symbol för kungens eller hövdingens "rike" och "auktoritet". Vid dessa helgedomar fanns rituella restriktioner. Bland annat fick man inte bära vapen eller utföra våldshandlingar där. Härskarbenämningarna vorðr véstalls och vés valdr indikerar att det var hövdingens eller kungens roll 
att övervaka dessa regler. Om härskaren kunde skydda kulten och kultplatserna kunde han också skapa en god förbindelse med den mytiska världen. Den förbindelsen kunde då få en kosmisk betydelse, det vill säga att landet som han styrde över förvandlades till ett paradisiskt tillstånd, där åkrarna gav goda skördar med mera. Om en hövding eller kung inte kunde skydda sin helgedom var det en stor förödmjukelse och hans makt kollapsade. Han kunde inte längre betraktas som en legitim härskare. En attack mot fiendehövdingens helgedom och ett medvetet skändande av den kunde således vara en bra strategi för en utmanare som strävade efter makten. I uppsatsen har jag gett exempel på källor som tycks spegla sådana performativa handlingar och ritualer. För att underbygga hypotesen krävs dock en mer omfattande empirisk undersökning av bland annat det arkeologiska materialet.

\section{Noter}

I. Egils saga Skalla-Grimssonar ([red.] Sigurður Nordal): I48-163; Egils saga (övers. Johansson): I38-I 50.

2. "Svá skyldi goð gjalda, / gram reki bond af londum / reið sé rogn ok Óðinn, / rọn mins féar hōnum; folkmýgi lát flýja, / Freyr ok Njorðr, af jorðum / leiðisk lofða striði / landōss, panns vé grandar." "Må gudarna driva kungen ut ur landet. De ska gälda honom för stölden av mitt gods. Oden och gudarna är vreda. Må Frö och Njord driva bort folkets fiende, Tor vredgas på tingsbrytaren" (Egils saga Skalla-Grimssonar ([red.] Sigurður Nordal): I63; Egils saga (övers. Johansson): I 50).

3. Frense 1982: 157, I75.

4. Lincoln I994: 55-73.

5. Jfr Sundqvist 20 I0.

6. Jfr Sundqvist 2007 och 20 I I.

7. Ett klassiskt exempel på en performativ talakt är "härmed förklarar jag er som äkta makar". Orden innebär en faktiskt förändring. Se t.ex. Austin I962; Tambiah I979; Bell I997: 68 f.; Rappaport I999: I24-I 26; Hall 2000; Grimes 2006: $390 \mathrm{f}$.

8. Liknande hypoteser om en rituell krigföring i anslutning till järnåldershallar bevittnade $\mathrm{i}$ arkeologiska källor har tidigare förts 
fram i t.ex. Herschend I998: 36 f.; Nordberg 2003: I 5; Andrén 20I4: 69-II 5. Docent Erik af Edholm har gjort mig uppmärksam på att liknande fenomen även förekommer i Indien, i hinduiska sammanhang. Se t.ex. Davis I999: 5 I-87.

9. Se t.ex. Vikstrand 200I: 298.

Io. Heggstad et al. I993: I80 har helgi (f.) 'heilagskap, det å vere heilag el. ukrenkjeleg'; jfr helga 'helge, gjere heilag, vie', 'gjere ukrenkjeleg, fredlyse'; medan heilagr (adj.) förklaras 'heilag', 'heilag, ukrenkjeleg' (Heggstad et al. I993: I76). Se även diskussion hos Baetke (1942) och Vikstrand (200I: 226-236).

I I. Jfr Widengren I963: 49-5 I och Nordberg 20I0: I8.

I2. Vikstrand 20I0: 58.

I3. Baetke I942: 60, 68, $207 \mathrm{f}$.

I4. I följande eddadikter syftar vé på gudarnas mytiska boning: Vafðrúðnismál (Edda ([red.] Neckel \& Kuhn)): 5I (vé goða); Grimnismál (Edda ([red.] Neckel \& Kuhn)): I3 (valda véum); och Hyndluljóð (Edda ([red.] Neckel \& Kuhn)): I (til vés heilags). I t.ex. Vellekla (Den norsk-islandske skjaldedigtning ([red.] Finnur Jónsson)): I 5 (vé banda) syftar det på en kultplats i människornas värld (se nedan).

I 5. Vikstrand 200I: 298-365.

I6. Vikstrand 2010: 58-66.

I7. "[...] a sacrifice in $\mathrm{Vi}[\ldots]$ 'Do not persist in burning the man or his church, since it stands at $\mathrm{Vi}$, below the cliff'." "[...] blotan $i \mathrm{Vi}[\ldots]$ Herpin ai brenna mann ella kirkiu hans, py et han standr $i$ Vi, firir nipan klintu" (Guta Saga ([red. \& övers.] Peel): 8 f.).

I8. Egils saga Skalla-Grimssonar ([red.] Sigurður Nordal): 56; Den celdre Frostathings-Lov (Norges Gamle Love indtil 1387 ([red.] Keyser \& Munch)), I: I27.

I9. Ynglingatal (Den norsk-islandske skjaldedigtning $\mathrm{B}_{\mathrm{I}}$ ([red.] Finnur Jónsson)): I 2.

20. Snorri Sturluson, Edda: Háttatál ([red.] Faulkes): 36.

2I. Alexanders saga ([red.] van Weenen): 4I översätter cruenta faces till dreyrugir vébrandar; se i Fritzner (1986-96) I954, 3: 882.

22. Snorri Sturluson, Edda: Skaldskaparmál ([red.] Faulkes): 6I. 
23. Hållans Stenholm 20I0; Svensson 20 IO.

24. Vikstrand 200I: $238-249$.

25. Zachrisson 2004; 2010.

26. Landnámabók ([red.] Jakob Benediktsson): 307.

27. Heggstad et al. I993.

28. "[...] hann vá víg í véum ok vard útloegr [...] / [...] hann vá víg í véum ok vardútlagr [...]" (Landnámabók ([red.] Jakob Benediktsson): $\left.\mathrm{S}_{72}, \mathrm{H} 60\right)$.

29. "[...] en menn váru allir vápnlausir inni, pvi at par var Hofshelgi [...] Eyvindr hafði vegit i véum ok var hann vargr orðinn, ok varð pegar brott at fara" (Egils saga Skalla-Grimssonar ([red.] Sigurður Nordal): 49).

30. "Eigi er pat siðr at bera vápn í hofit, ok muntu verða fyrir goða reiði, ok er slíkt ófoert, nema boetr komi fram" (Vatnsdoela saga ([red.] Einar Ól. Sveinsson): kap. I7). "Det är svår osed att bära vapen i gudahov, och du blir utsatt för gudarnas vrede; sådant går inte utan att böter gäldas" (Vatnsdalssagan (övers. Ohlmarks): kap. I7). Jfr Hrafn [...] hafði sverð gott; pat bar hann í hof; pví tók Ingimundr af honum sverðit (Landnámabók ([red.] Jakob Benediktsson): S I79).

3I. Jansson I985: 4I.

32. Se t.ex. Eliade (I949) I974; Smith I987.

33. Strömbäck I928.

34. "En er hann kom vestr fyrir Breiðafjorð, pá skaut hann fyrir borð ondvegissúlum sinum; par var skorinn á Pórr. [...] hét hann pvi at helga Pór allt landnám sitt ok kenna við hann. [...] ok gerði par hof mikit ok helgaði Pór. [...] svá mikinn átrúnað á fjall pat, er stóð i nesinu, er hann kallaði Helgafell, at pangat skyldi engi maðr ópveginn lita, ok par var svá mikil friðhelgi, at øngu skyldi granda i fjallinu, hvárki fé né monnum, nema sjálft gengi á braut" (Landnámabók ([red.] Jakob Benediktsson): S 85, H 73; jfr Eyrbyggia saga ([red.] Einar Ól. Sveinsson \& Matthías Pórðarson): kap. 4).

35. "Pórhaddr inn gamli var hofgoði i Prándheimi á Mæeri. Hann fýstist til Íslands ok tók ádr ofan hofit ok hafði með sér hofsmoldina ok súlurnar. En hann kom i Stoðvarfiorð ok lagði Mæerinahelgi á allan 
fiorðinn ok lét engu tortíma par nema kvikfé heimilu" (Landnámabók ([red.] Jakob Benediktsson): S 297, H 258).

36. ”Pat polðu eigi Pórsnesingar, er peir vildu saurga svá helgan voll. [...]" (Landnámabók ([red.] Jakob Benediktsson): S 85, H 73; jfr Eyrbyggja saga ([red.] Einar Ól. Sveinsson \& Matthías Pórðarson): kap. 9-10)).

37. Landnámabók ([red.] Jakob Benediktsson): S 85, H 73.

38. Ynglingatal (Den norsk-islandske skjaldedigtning $\mathrm{B}_{\mathrm{I}}$ ([red.] Finnur Jónsson)): 7-I4.

39. Se Krag I99I. Kritisk mot Krags uppfattning är t.ex. Fidjestøl (I994), Sundqvist (I995), Dillmann (2000), Bergsveinn Birgisson (2008) och McKinnell (2010).

40. Se vidare om tolkningen av kenningen i Sundqvist 2002: I96 f.

4I. Sigurðardrápa 6 (Den norsk-islandske skjaldedigtning BI ([red.] Finnur Jónsson): 69 f.).

42. Hákonarmál I 8 (Den norsk-islandske skjaldedigtning BI ([red.] Finnur Jónsson): 59).

43. Se t.ex. Düwel 1992.

44. Peterson 2007: 257.

45. Peterson 2007: 257.

46. "Loptr fór útan et priðja hvert sumar fyrir hond peira Flosa beggja, móðurbróður sins, at blóta at hofi pví, er Porbjorn móðurfaðir hans hafði varðveitt" (Landnámabók ([red.] Jakob Benediktsson): 368).

47. "[...] hann [Pórólfr] varðveitti par i eyjunni Pórshof [...]" (Eyrbyggia saga 3 ([red.] Einar Ól. Sveinsson \& Matthías Pórðarson): 6). Jfr "Hann varðveitti pá hof; var hann pá kallaðr Snorri goði; [...]" (Eyrbyggja saga I5 ([red.] Einar Ól. Sveinsson \& Matthías Pórðarson): 27).

48. Fabech I99I; I994; Fabech \& Näsman 20I3; kritiskt betraktat i Zachrisson I998: II 8 och Hedeager I999.

49. Munch 2003; Lamm 2004.

50. Se Olsen I909; kritiskt betraktat i Ratke \& Simek 2006 och Watt 2007. 
5I. Jfr Drobin I99I; Drobin \& Keinänen 200I; Hedeager 200I; 20II; Nordberg 2003; 20IO; Andrén 2004; Zachrisson 2004; Sundqvist 2007; 20 II.

52. Jfr Lincoln I994.

53. Herschend I998.

54. Herschend I998: $36 \mathrm{f}$.

55. Nordberg 2003: I I 5; jfr Andrén 2014: 69-II 5.

56. Holmquist-Olausson 200I: I 4 f. och Nordberg 2003: I I 6

57. Eyrbyggja saga ([red.] Einar Ól. Sveinsson \& Matthías Pórðarson): kap. го.

58. "[...] letu brjóta ofan hofit ok taka allt fé ok allt skraut ór hofinu ok af goðinu [goðinum]" (Snorri Sturluson, Óláfs saga Tryggvasonar 59 = Heimskringla ([red.] Bjarni Aðalbjarnarson), I: 308).

59. "Siðan lét Óláfr konungr brenna hofit" (Snorri Sturluson, Óláfs saga Tryggvasonar 59 = Heimskringla ([red.] Bjarni Aðalbjarnarson), I: 308).

60. Snorri Sturluson, Óláfs saga Tryggvasonar $69=$ Heimskringla ([red.] Bjarni Aðalbjarnarson), I: 3 I 8 ; jfr Odd Snorrason, Óláfs saga Tryggvasonar ([red.] Ólafur Halldórsson): $279 \mathrm{f}$.

6I. Se Beda Venerabilis, Opera historica ([övers.] King), I: 30-32; 2: I $5 ; 3: 30$.

62. Adam av Bremen, Gesta Hammaburgensis ([red.] Schmeidler), 4: 30.

63. Snorri Sturluson, Óláfs saga Tryggvasonar 59 = Heimskringla ([red.] Bjarni Aðalbjarnarson), I: 24I f.; Olav Tryggvassons saga (övers. Johansson): $20 \mathrm{I}$.

64. Jfr Ström I98I.

\section{Referenser}

Källor

[Adam av Bremen] [d. Io80-t.], Gesta Hammaburgensis ecclesiae pontificum / Hamburgische Kirchengeschichte (Scriptores Rerum Germanicarum in usum scholarum ex Monumentis Germaniae 
Historicis Separatim Editi [63]). [Red.] Bernhard Schmeidler. Hannover I9I7: Hahnsche Buchhandlung.

Alexanders saga [(ca I I 80) I 263-64]: AM 5 I 9 a $4^{\circ}$ in the Arnamagncean Collection, Copenhagen (Manuscripta Nordica 2). [Red.] Andrea de Leeuw van Weenen. Copenhagen 2009: Museum Tusculanum Press.

[Beda Venerabilis] [d. 735], Opera historica (Loeb Classical Library). I-2. [Övers.] John Edward King. Cambridge, MA, (I930) I962-63: Harvard University Press.

[Beowulf] [700-t.?-rooo-t.?]. Klaeber's Beowulf and the Fight at Finnsburg (Toronto Old English Series 2I). [Red.] R. D. Fulk \& Robert E. Bjork \& John D. Niles. Toronto 2008: University of Toronto Press.

Edda [800-t.-Iooo-t.]: die Lieder des Codex Regius nebst verwandten Denkmälern. I, Text. [Red.] Gustav Neckel \& Hans Kuhn. Heidelberg (I9I4) I983: Carl Winter Universitätsverlag. (5 uppl.)

Egils saga Skalla-Grímssonar [I 220-30] (Íslenzk fornrit 2). [Red.] Sigurður Nordal. Reykjavík I933: Hið íslenzka fornritafélag.

\section{Atlantis.}

Egils saga. Övers. Karl G. Johansson. Stockholm I992:

Eyrbyggja saga [början av I200-t.] (Eyrbyggja saga, Brands páttr örva, Eiríks saga rauða, Grœnlendinga saga, Grœnlendinga páttr) (Íslenzk fornrit 4), s. 3-I 84. [Red.] Einar Ól. Sveinsson \& Matthías Pórðarson. Reykjavík (I935) I985: Hið íslenzka fornritafélag

Fagrskinna [före I 250]. Ágrip af Nóregskonunga sogum, FagrskinnaNóregs konunga tal (Íslenzk fornrit 29), s. 57-364. [Red.] Bjarni Einarsson. Reykjavík I 985 : Hið íslenzka fornritafélag.

Flateyjarbók [1387-94]. I-3. [Red.] Guðbrandur Vigfússon \& C. R. Unger. Christiania I 860-68: Malling.

Guta Saga: The History of the Gotlanders [1220-t.] (Text Series I2). [Red. \& övers.] Christine Peel. London I999: Viking Society for Northern Research.

Hákonarmál [960-t.], se Den norsk-islandske skjaldedigtning ([red.] Finnur Jonsson). 
Landnámabók [ca I 200]. Íslendingabók, Landnámabók (Íslenzk fornrit I), s. 3 I-397. [Red.] Jakob Benediktsson. Reykjavík I986: Hið íslenzka fornritafélag.

Norges Gamle Love indtil I387. I-3. Red. Rudolf Keyser \& P. A. Munch. Christiania I 846-49: Grøndahl.

Den norsk-islandske skjaldedigtning 800-I400. A, I-2; B, I-2. [Red.] Finnur Jónsson. København (I9I2-I 5) I967-73: Rosenkilde og Bagger.

Oddr Snorrason [sl. av I Ioo-t.], Óláfs saga Tryggvasonar. Fœreyinga saga, Óláfs saga Tryggvasonar (Íslenzk fornrit 25), s. I25-362. [Red.] Ólafur Halldórsson. Reykjavík 2006: Hið íslenzka fornritafélag.

Óláfs saga Tryggvasonar, se Snorri Sturluson, Heimskringla ([red.] Bjarni Aðalbjarnarson.

Sigurdardrápa [ca 960], se Den norsk-islandske skjaldedigtning ([red.] Finnur Jonsson).

Snorri Sturluson [d. I24I], Edda: Prologue and Gylfaginning. [Red.] Anthony Faulkes. London 1988: Viking Society for Northern Research.

Edda: Skáldskaparmál. I, Introduction, Text and Notes. [Red.] Anthony Faulkes. London 1998: Viking Society for Northern Research.

- Edda: Háttatál. [Red.] Anthony Faulkes. Oxford I99I: Clarendon Press.

Snorres Edda. Övers. Karl G. Johansson \& Mats Malm. Stockholm I997: Fabel.

- Heimskringla I-3 (Íslenzk fornrit 26-28). [Red.] Bjarni Aðalbjarnarson. Reykjavík (I94I, I945, I95I) I979: Hið íslenzka fornritafélag.

Olav Tryggvasons saga. Nordiska kungasagor I, s. I 87-305. Övers. Karl G. Johansson. Stockholm I99I: Fabel bokförlag.

Vatnsdæla saga [sl. av I 200-t.]. Vatnsd ela saga [...] (Íslenzk fornrit 8), s. 3-I3 I. [Red.] Einar Ól. Sveinsson. Reykjavík ı939: Hið íslenzka fornritafélag. 
Vatnsdalssagan. De isländska sagorna. 4, Sagorna från mellersta och östra Nordisland, s. 5-7. Övers. Åke Ohlmarks. Stockholm I964: Stenvik.

Ynglingatal [ca 890], se Den norsk-islandske skjaldedigtning ([red.] Finnur Jonsson).

\section{Sekundärlitteratur}

Andrén, Anders. 2004. I skuggan av Yggdrasil: trädet mellan idé och realitet i nordisk tradition. Ordning mot kaos: studier av nordisk förkristen kosmologi, s. 389-430.

20I4. Tracing Old Norse Cosmology: The World Tree, Middle Earth, and the Sun in Archeological Perspectives (Vägar till Midgård I6). Lund: Nordic Academic Press.

Austin, John L. I962. How to do Things with Words (The William James Lectures I955). [Red.] J. O. Urmson. Cambridge, MA: Harvard University Press.

Baetke, Walter. I942. Das Heilige im Germanischen. Tübingen: Max Niemeyer Verlag.

Bell, Catherine. 1997. Ritual: Perspectives and Dimensions. New York: Oxford University Press.

Bergsveinn Birgisson. 2008. Inn i skaldens sinn: kognitive, estetiske og historiske skatter $i$ den norrøne skaldediktningen. Bergen: Universitetet i Bergen.

Davis, Richard H. I999. Lives of Indian Images. Princeton: Princeton University Press.

Dillmann, Francois-Xavier. 2000. Chronique des études nordiques. Proxima Thulé: revue d'études nordiques 4, s. IOI-I I 2.

Drobin, Ulf. I99I. Mjödet och offersymboliken i fornnordisk religion. Studier i religionshistoria: tillägnade Åke Hultkrantz professor emeritus den I juli I986, s. 97-I4 I [Red.] Louise Bäckman \& Ulf Drobin \& Per-Arne Berglie. Löberöd: Plus Ultra.

Drobin, Ulf \& Marja-Liisa Keinänen. 200I. Frey, Veralden olmai och Sampo. Kontinuitäten und Brüche in der Religionsgeschichte: Festschrift für Anders Hultgård zu seinem 65. Geburtstag am 
23.I 2.200I (Ergänzungsbände zum Reallexikon der germanischen Altertumskunde 3I), s. I36-I69. [Red.] Michael Stausberg. Berlin: de Gruyter.

Düwel, Klaus. I992. Zur Auswertung der Brakteateninschriften: Runenkenntnis und Runeninschriften als OberschichtenMerkmale. Der historische Horizont der Götterbild-Amulette aus der Übergangsepoche von der Spätantike zum Frühmittelalter (Abhandlungen der Akademie der Wissenschaften in Göttingen. Philologisch-historische Klasse 3, 200), s. 32-90. [Red.] Karl Hauck. Göttingen: Vandenhoeck \& Ruprecht.

Eliade, Mircea. (1949) I974. Patterns in Comparative Religion. [Övers.] Rosemary Sheed. New York: Sheed \& Ward.

Fabech, Charlotte. I99I. Samfundsorganisation, religiøse ceremonier og regional variation. Samfundsorganisation og regional variation: Norden $i$ romersk jernalder og folkevandringstid (Jysk arkæologisk selskabs skrifter 27), s. 283-304. Red. Charlotte Fabech \& Jytte Ringtved. Højbjerg: Jysk arkæologisk selskab.

I994. Reading society from the cultural landscape: South Scandinavia between sacral and political power. The Archaeology of Gudme and Lundeborg (Arkæologiske studier Io), s. I69-183. [Red.] Poul-Otto Nielsen \& Klave Randsborg \& Henrik Thrane. København: Akademisk forlag.

Fabech, Charlotte \& Ulf Näsman. 20I3. Ritual landscapes and sacral places in the first millennium AD in South Scandinavia. Sacred Sites and Holy Places: Exploring the Sacralization of Landscape through Time and Space (Studies in the Early Middle Ages I I), s. 53-109. [Red.] Sæbjørg Walaker Nordeide \& Stefan Brink. Turnhot: Brepols.

Fidjestøl, Bjarne. I994. [Anm. av Krag I99I]. Maal og minne I994: 3-4, S. I9I-I99.

Frense, Bo. 1982. Religion och rätt: en studie till belysning av relationen religion-rätt i förkristen nordisk kultur. Lund: Lunds universitet.

Fritzner, Johan. (1886-96) I954. Ordbog over det gamle norske sprog. I-3. Oslo: Tryggve Juul Møller Forlag. (2 uppl.)

Grimes, Ronald L. 2006. Performance. Theorizing Rituals: Issues, Topics, Approaches, Concepts (Studies in the History of Religions 
I 4: I), s. 379-394. [Red.] Jens Kreinath \& Jan Snoek \& Michael Stausberg. Leiden: Brill.

Hall, Kira. 2000. Performativity. Journal of Linguistic Anthropology 9: I-2, s. I $84-187$.

Hedeager, Lotte. I999. Sacred topography: depositions of wealth in the cultural landscape. Glyfer och arkeologiska rum - en vänbok till Jarl Nordbladh (Gotarc A, 3), s. 229-252. Red. Anders Gustafsson \& Håkan Karlsson. Göteborg: Göteborgs universitet.

200I. Asgard reconstructed? Gudme - a 'central place' in the north. Topographies of Power in the Early Middle Ages (The Transformation of the Roman World 6), s. 467-507. [Red.] Mayke de Jong \& Frans Theuws \& Carine van Rhijn. Leiden: Brill.

20I I. Iron Age Myth and Materiality: An Archaeology of Scandinavia AD 400-I000. London: Routledge.

Heggstad, Leiv \& Marius Hæggstad \& Alf Torp \& Finn Hødnebø $\&$ Erik Simensen (I909) I990. Norrøn ordbok (Samlagets oppslagsverk). Oslo: Samlaget. (4 uppl.)

Herschend, Frands. I998. The Idea of the Good in Late Iron Age Society (Occasional Papers in Archaeology I 5). Uppsala: Institutionen för arkeologi och antik historia, Uppsala universitet.

Holmquist-Olausson, Lena. 200I. Birkas befästningsverk - resultat från de senaste årens utgrävningar. Birkas krigare, s. 9-15. Red. Michael Olausson. Stockholm: Arkeologiska forskningslaboratoriet, Stockholms Universitet

Hållans Stenholm, Ann-Marie. 20 Io. Lilla Ullevi - en kultplats. Makt, kult och plats: högstatusmiljöer under äldre järnåldern, s. 3 I-38.

Jansson, Sven B. F. I98 5. Runinskrifter i Sverige. Stockholm: AWE Geber.

Krag, Claus. I99I. Ynglingatal og Ynglingesaga: en studie i historiske kilder (Studia humaniora 2). Oslo: Universitetsforlaget.

Lamm, Jan Peder. 2004. Figural gold foils found in Sweden: a study based on the discoveries from Helgö. Excavations at Helgö. I6, Exotic and Sacral Finds from Helgö, s. 4 I-I42. Stockholm: Kungl. Vitterhets-, historie och antikvitetsakademien.

Lincoln, Bruce. I994. Authority: Construction and Corrosion. Chicago: University of Chicago Press. 
Makt, kult och plats: högstatusmiljöer under äldre järnåldern (Arkeologi i Stockholms län 5). Red. Peter Bratt \& Richard Grönwall. Stockholm 20I0: Stockholms läns museum

McKinnell, John. 20I0. Ynglingatal - a minimalist interpretation. Scripta Islandica 60, s. 23-48.

Munch, Gerd Stamsø. 2003. Borg as a pagan centre. Borg in Lofoten: A Chieftain's Farm in North Norway (Arkeologisk skriftserie I), s. 253-263. [Red.] Gerd Stamsø Munch \& Olav Sverre Johansen \& Else Roesdahl. Trondheim: Tapir.

Nordberg, Andreas. 2003. Krigarna i Odins sal: dödsföreställningar och krigarkult i fornnordisk religion. Stockholm: Stockholms universitet.

20IO. Kultplatser, helgedomar och heliga platser. Makt, kult och plats: högstatusmiljöer under äldre järnåldern, s. I6-22.

Olsen, Magnus. 1909. Fra gammalnorsk myte og kulthus. Maal og minne I909, s. I7-36.

Ordning mot kaos: studier av nordisk förkristen kosmologi (Vägar till Midgård 4). Red. Anders Andrén \& Kristina Jennbert \& Catharina Raudvere. Lund 2004: Nordic Academic Press

Peel, Christine. I999. Guta Saga: The History of the Gotlanders (Text Series I2). London: Viking Society for Northern Research.

Peterson, Lena. 2007. Nordiskt runnamnslexikon. Uppsala: Institutet för språk- och folkminnen. ( 5 uppl.)

Rappaport, Roy. A. (I999) 2000. Ritual and Religion in the Making of Humanity (Cambridge Studies in Social and Cultural Anthropology I Io). Cambridge: Cambridge University Press.

Ratke, Sharon \& Rudolf Simek. 2006. Guldgubber: relics of Pre-Christian law rituals? Old Norse Religion in Long-Term Perspectives (Vägar till Midgård 8), s. 259-264. [Red.] Anders Andrén \& Kristina Jennbert \& Catharina Raudvere. Lund: Nordic Academic Press.

Smith, Jonathan Z. I987. To Take Place: Toward Theory in Ritual (Chicago Studies in the History of Judaism). Chicago: University of Chicago Press. 
Ström, Folke. I98I. Poetry as an instrument of propaganda: Jarl Hákon and his poets. Speculum Norroenum: Norse Studies in Memory of Gabriel Turville-Petre, s. 440-458. [Red.] Ursula Dronke \& Guðrún P. Helgadóttir \& Gerd Wolfgang Weber \& Hans Bekker-Nielsen. Odense: Odense University Press.

Strömbäck, Dag. 1928. Att helga land: studier i Landnáma och det äldsta rituella besittningstagandet. Festskrift tillägnad Axel Hägerström den 6 september 1928 av filosofiska och juridiska föreningarna i Uppsala, s. I98-220. Uppsala: Almqvist \& Wiksell.

Sundqvist, Olof. I995. [Anm. av Krag I99I]. Svensk religionshistorisk årsskrift 5, s. I 58-162.

2002. Freyr's Offspring: Rulers and Religion in Ancient Svea Society (Acta Universitatis Upsaliensis. Historia religionum 2I). Uppsala: Uppsala University Library.

2007. Kultledare $i$ fornskandinavisk religion (Occasional Papers in Archaeology 4I). Uppsala: Institutionen för arkeologi och antik historia, Uppsala universitet.

20I0. Vi-platsernas väktare: till frågan om kultledare i det förkristna Mälarområdet. Makt, kult och plats: högstatusmiliöer under äldre järnåldern, s. 90-95.

20II. Gudme on Funen: a central sanctuary with cosmic symbolism? The Gudme / Gudhem Phenomenon (Schriften des Archäologischen Landesmuseums. Ergänzungsreihe 6), s. 63-76. [Red.] Oliver Grimm \& Alexandra Pesch. Neumünster: Wachholtz.

Svensson, Kenneth. 20I0. Götavi - en vikingatida kultplats i Närke. Makt, kult och plats: högstatusmiliöer under äldre järnåldern, s. $68-78$.

Tambiah, Stanley J. I979. A performative approach to ritual. Proceedings of the British Academy 65, s. I I3-I69.

Vikstrand, Per. 200I. Gudarnas platser: förkristna sakrala ortnamn i Mälarlandskapen (Acta Academiae Regiae Gustavi Adolphi 77 I Studier till en svensk ortnamnsatlas I7). Uppsala: Kungl. Gustav Adolfs akademien för svensk folkkultur.

20I0. Ortnamn och den äldre järnålderns högstatusmiljöer. Makt, kult och plats: högstatusmiljöer under äldre järnåldern, s. 23-30. 
Watt, Margarethe. 2007. Kan man tyde guldgubbernes gestussprog. Kult, guld och makt - ett tvärvetenskapligt symposium $i$ Götene (Historieforum Västra Götaland. B, Vetenskapliga rapporter och småskrifter 4), s. I33-I48. Red. Ingemar Nordgren. Skara: Historieforum Västra Götaland.

Widengren, Geo. 1963. Religionens ursprung. Stockholm: Aldus / Bonniers.

Zachrisson, Torun. 1998. Gård, gräns, gravfält: sammanhang kring ädelmetalldepåer och runstenar från vikingatid och tidig medeltid $i$ Uppland och Gästrikland (Stockholm Studies in Archaeology I 5 ). Stockholm: Stockholms universitet.

— 2004. Det heliga på Helgö och dess kosmiska referenser. Ordning mot kaos: studier av nordisk förkristen kosmologi, s. $343-388$.

20Iо. Helgö - mer än ett vi. Makt, kult och plats: högstatusmiljöer under äldre järnåldern, s. 79-88. 